Original Research Paper

\title{
Pelatihan Pembuatan Eco-enzyme sebagai Handsanitizer di RT.001/008 Kelurahan Bulakrejo Kecamatan Sukoharjo Kabupaten Sukoharjo dalam Upaya Mewujudkan Desa Mandiri Tangguh Covid-19
}

\author{
Ratna Dewi Eskundari ${ }^{1}$, Tri Wiharti ${ }^{1}$, Nur Rokhimah Hanik ${ }^{1}$

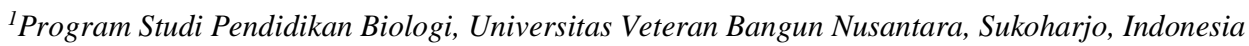

https://doi.org/10.29303/jpmpi.v3i2.1256

Sitasi: Eskundari, R. D., Wiharti, T \& Hanik, N. R. (2021). Pengembangan Objek Wisata Kampung Wisata Sasak Ende Melalui Penataan Destinasi, Optimalisasi Digital Promotion dan Sumber Daya Manusia di Desa Sengkol. Jurnal Pengabdian Magister Pendidikan IPA 4(4)

\section{Article history}

Received:15 November 2021

Revised: 05 Desember 2021

Accepted: 25 Desember 2021

*Corresponding Author: Ratna Dewi Eskundari, Universitas Veteran Bangun Nusantara,

Sukoharjo, Indonesia

Email:

ratnaeskundari87@gmail.com

\section{Pendahuluan}

$\mathrm{P}$ andemi Covid-19 sampai saat ini masih menjadi salah satu fokus utama dunia. Pandemi mengakibatkan kemunduran ekonomi, misalnya banyak pemutusan hubungan kerja (PHK) dan penurunan daya beli masyarakat. Di Indonesia khususnya, perekonomian pada kuartal ke-II tahun 2020 menurun hingga $5,32 \%$ dan sektor yang paling terdampak adalah sektor rumah tangga (lipi.go.id). Kondisi ini sangat terlihat apabila dilihat dari konsumsi rumah tangga yang menurun sehingga akhirnya berdampak pula pada industri dan usaha mikro, kecil, dan menengah (UMKM). Selain itu, PHK, pemotongan gaji, ataupun hal lain yang berkaitan dengan penurunan sumber pendapatan pekerja, mengakibatkan dampak negatif pada perekonomi Indonesia, terutama pada sektor rumah tangga. Hasil survei LIPI pada tahun 2020 memperlihatkan bahwa sektor rumah

\begin{abstract}
The Covid-19 pandemic which has lasted for about 2 years has training to partner communities regarding the manufacture of one of the ecoenzyme diversification products in the form of an eco-handsanitizer. counseling a sequence of situation analysis of partner communities, evaluation results showed that the community partners can make eco-
\end{abstract} Keywords: Covid-19; Ecoenzyme; Eco-handsanitizer.

tangga mengalami keterpurukan ekonomi, sehingga pemerintah bergerak cepat dalam mengatasinya, salah satunya dengan meluncurkan program bantuan pemerintah berupa bantuan sosial (http://lipi.go.id/siaranpress/survei-dampakpandemi-covid-19-terhadap-ekonomi-rumahtangga-indonesia/22123).

Dampak negatif dari pandemi Covid-19 memang sangat luas, hampir seluruh masyarakat dunia merasakannya. Salah satu RT di Kelurahan Bulakrejo, Kecamatan Sukoharjo, Kabupaten Sukoharjo yaitu RT.001/008, juga merasakan dampak negatif dari masa pandemi sekarang ini karena ada beberapa di antara warga RT tersebut yang terkena PHK maupun menurun pendapatannya. Hal ini tentunya mendorong masyarakat di RT tersebut untuk berusaha sehingga dapat bertahan dalam kondisi pandemi ini, salah satunya adalah dengan mengembangkan pertanian organik, walaupun hanya pada skala rumah tangga. Salah satu usaha mereka dalam mengelola 
pertanian organik skala rumah tangga adalah memanfaatkan pupuk organik dengan pengetahuan terkait pembuatan pupuk organik hanya sebatas pengetahuan berdasarkan cobacoba.

Berdasarkan kondisi ini, masyarakat di RT. 001/008; yang selanjutnya disebut dengan "masyarakat mitra" dalam kegiatan pengabdian masyarakat ini; memerlukan pendampingan dalam rangka pemberdayaan masyarakat, khususnya dalam kondisi pandemi seperti sekarang. Di sisi lain, keberadaan sampah organik dapur kurang dimanfaatkan oleh masyarakat mitra. Sampah rumah tangga dari mitra, kebanyakan hanya dibuang di tempat sampah ataupun kadang dibakar; sehingga dapat dikatakan bahwa pemanfaatan sampah belum tercapai, khususnya untuk sampah organik. Beberapa hal inilah yang mendorong tim Pengabdian kepada Masyarakat dari Program Studi Pendidikan Biologi, Universitas Veteran Bangun Nusantara tergerak untuk memberdayakan masyarakat mitra melalui program pemanfaatan sampah rumah tangga, khususnya sampah organik yang berasal dari sisa buah dan sayur, untuk menghasilkan larutan ajaib yaitu ekoenzim; yang dapat digunakan sebagai bahan pembuatan pupuk organik maupun handsanitizer.

Ekoenzim merupakan hasil fermentasi sisa sayur dan atau buah yang masih layak, dengan gula (molase atau aren) selama sekitar 3 bulan. Bagian dari ekoenzim semuanya bermanfaat, yaitu bagian ampasnya dapat digunakan sebagai pupuk organik, mapun bagian larutannya dapat digunakan sebagai pupuk cair organik, desinfektan, pembersih, mapaun handsanitizer. Karena keunggulannya yang berifat ramah lingkungan, maka diharapkan masyrakat mitra dapat membuat dan memanfaatkan ekoenzim dalam kehidupan sehari-hari, misalnya sebagai pupuk organik yang dapat membantu dalam kelangsungan pertanian organik skala rumah tangga, ataupun handsanitizer yang merupakan salah satu produk yang dapat dikatakan "wajib" dimiliki oleh setiap orang saat masih dalam kondisi pandemi seperti ini. Salah satu manfaat handsanitizer berbahan dasar ekoenzim adalah ramah lingkungan dan rendah iritasi. Hasil penelitian Mavani et al. (2020) menunjukkan bahwa handsanitizer yang dibuat dari larutan ekoenzim ternyata mempunyai aktivitas antimikroba yang setara dengan Natrium hipoklorit $(\mathrm{NaOCl})$ kadar $2.5 \%$. Selain itu, terdapat laporan penelitian bahwa kombinasi larutan eco-enzim dengan ekstrak bunga Plumeria alba dapat dijadikan handsanitizer terhadap pertumbuhan bakteri Staphyococcus aureus (Rahayu et al. 2021). Aktivitas antimikroba juga dilaporkan terdapat pada lidah buaya terhadap pertumbuhan bakteri gram positif maupun negatif (Lawrence et al. 2009). Gel lidah buaya juga pernah digunakan untuk campuran handsanitizer berbahan dasar alkohol $70 \%$ (Lusiana et al. 2020). Hal-hal inilah yang menjadikan dasar pemikiran tim Pengabdian kepada Masyarakat dari Prodi Pendidikan Biologi untuk mengkombinasikan larutan eco-enzim dengan tanaman herbal yang mempunyai aktivitas antimikroba sekaligus mudah didapat, misalnya lidah buaya.

Masyarakat RT.001/008 Kelurahan Bulakrejo sebelumya sudah mendapatkan pelatihan berupa pembuatan ekoenzim dari tim Pengabdian kepada Masyarakat Kompetitif Bidang Ilmu (PMKBI) Prodi Pendidikan Biologi Univet Bantara Sukoharjo. Namun masyarakat masih kurang paham dalam bagaimana cara untuk membuat handsanitizer yang berbahan dasar ekoenzim karena output PMKBI adalah masyarakat mitra dapat membuat ekoenzim dengan baik dan benar, belum sampai ke diversifikasi produk ecoenzim lainnya misalnya sebagai handsanitizer. Dengan demikian, tim kami ingin mengadakan pelatihan pembuatan eco-handsanitizer dari ekoenzim dengan harapan dapat meningkatkan ketrampilan masyarakat dalam membuat ecohandsanitizer yang berbahan dasar ekoenzim, baik untuk digunakan sendiri dalam rangka tanggap pandemi Covid-19 atau untuk dijual. Dari hasil pertemuan tim dengan masyarakat disepakati bahwa masyarakat menerima 
program pengabdian masyarakat dari tim dosen serta mahasiswa Program Studi Pendidikan Biologi Universitas Veteran Bangun Nusantara Sukoharjo dengan membuat handsanitizer yang berbahan dasar ekoenzim. Tim kami mengikutsertakan beberapa masyarakat yang tinggal di RT tersebut untuk terlibat dalam kegiatan ini yaitu Kelompok Wanita Tani (KWT) Cendana.

\section{Metode}

Berdasarkan permasalahan yang dihadapi masyarakat RT. 001/008 Kelurahan Bulakrejo Kecamatan Sukoharjo Kabupaten Sukoharjo, solusi yang ditawarkan tentunya diperlukan sebagai bentuk kegiatan yang memberikan pengalaman dan pemahaman, dengan tujuan masyarakat mempunyai pengetahuan dan ketrampilan dalam pembuatan eco-handsanitizer yang berbahan dasar ekoenzim. Bentuk kegiatan pengabdian ini dilakukan dengan cara penyuluhan dan pelatihan antara lain:

1. Ceramah (penyampaian materi), berkaitan dengan seluk-beluk eco-handsanitizer yang berbahan dasar ekoenzim.

2. Diskusi dan tanya jawab. Diskusi dilakukan guna memecahkan permasalahan yang dihadapi masyarakat RT. 001/008 Kelurahan Bulakrejo Kecamatan Sukoharjo Kabupaten Sukoharjo pada saat pandemi seperti sekarang ini, salah satunya melalui pelatihan pembuatan ecohandsanitizer yang berbahan dasar ekoenzim.

3. Praktik membuat eco-handsanitizer yang berbahan dasar ekoenzim.

4. Pembimbingan dilakukan dalam pengarahan bagi mitra ketika berpraktik.

Selain itu, sebelum serta sesudah kegiatan penyuluhan dan pelatihan dilakukan, dilakukan evaluasi. Kegiatan ini dilakukan untuk mengetahui bagaimana pemahaman peserta terkait dengan kegiatan yang akan dan telah dilakukan. Evaluasi dilakukan 2 kali, yaitu: Pre-test, yaitu evaluasi yang dilakukan dengan cara observasi awal tentang kondisi mitra, dan Post-test, yaitu evaluasi yang dilakukan setelah kegiatan pengabdian selesai. Nilai program kegiatan dilakukan dengan membandingkan kondisi awal dengan kondisi akhir dari pengabdian.

\section{Hasil dan Pembahasan}

Kegiatan Pengabdian kepada Masyarakat (Pengabmas) ini diawali dengan diskusi terkait diversifikasi produk dari ekoenzim pada tanggal 27 September 2021; yang mana pelatihan pembuatan ekoenzim telah dilakukan pada Pengabmas sebelumnya (Juni 2021). Dari diskusi tersebut diperoleh hasil bahwa masyarakat mitra yang diwakili oleh ketua KWT Cendana, belum mengetahui produk-produk yang dapat dihasilkan dari ekoenzim, misalnya handsanitizer. Dengan penjelasan yang detail dari tim Pengabmas Prodi Pendidikan Biologi Universitas Veteran Bangun Nusantara, maka KWT Cendana; yang dalam hal ini diwakili oleh ketua KWT Cendana, setuju dilakukan penyuluhan dan pelatihan pembuatan eco-handsanitizer yang berbahan dasar larutan ekoenzim.

Pertemuan kedua antara tim Pengabmas Prodi Pendidikan Biologi Universitas Veteran Bangun Nusantara dengan KWT Cendana berlangsung pada tanggal 9 Oktober 2021 bertempat di rumah ketua KWT Cendana. Pada pertemuan ini dilakukan pretest terkait selukbeluk eco-handsanitizer yang berbahan dasar ekoenzim (Gambar 1). Hasil prestest menunjukkan bahwa anggota KWT Cendana belum mengetahui tentang tatacara pembuatan eco-handsanitizer yang mempunyai manfaat sama dengan handsanitizer berbahan dasar alkohol yang dijual di pasaran. Setalah dilakukan pretest tersebut, acara dilanjutkan dengan penyampaian materi terkait ecohandsanitizer dan terlihat bahwa anggota KWT Cendana antusias dalam menyimak penjelasan tentang pembuatan eco-handsanitizer dari tim Pengabmas Prodi Pendidikan Biologi Universitas Veteran Bangun Nusantara. Sesi tanya jawab selanjutnya dibuka setelah 
selesainya pemaparan materi tentang pembuatan eco-handsanitizer dan lagi-lagi anggota KWT Cendana sangat antusias yang ditandai dengan banyaknya pertanyaan yang diajukan, misalnya waktu simpan ecohandsanitizer dan keamanan eco-handsanitizer.

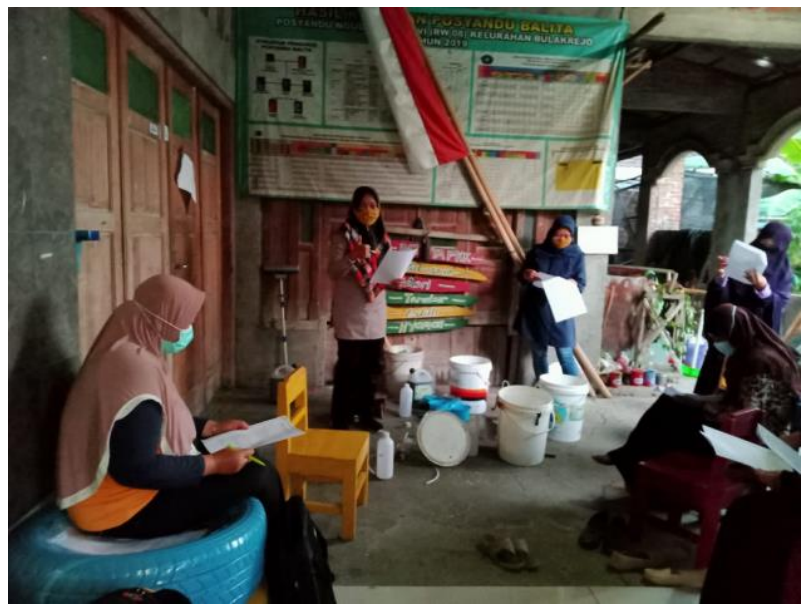

Gambar 1 Pelaksanaan pretest pada kegiatan Pengabmas terkait pembuatan ecohandsanitizer

Kegiatan praktik dan pembinaan pembuatan eco-handsanitizer selanjutnya dilakukan pada tanggal 25 November 2021 di rumah ketua KWT Cendana dan dihadiri oleh beberapa anggota KWT Cendana serta tim Pengabmas Prodi Pendidikan Biologi Universitas Veteran Bangun Nusantara yang terdiri dari tim dosen dan beberapa mahasiswa. Awalnya tim dosen memberikan pemaparan tata cara pembuatan eco-handsanitizer (Gambar 2) dan selanjutnya praktik langsung pembuatannya dibantu oleh mahasiswa (Gambar 3). Semua anggota KWT Cendana terlihat antusias dalam acara ini yang ditandai dengan perhatian yang penuh dalam praktik pembuatan ecohandsanitizer dan juga pada sesi tanya jawab.
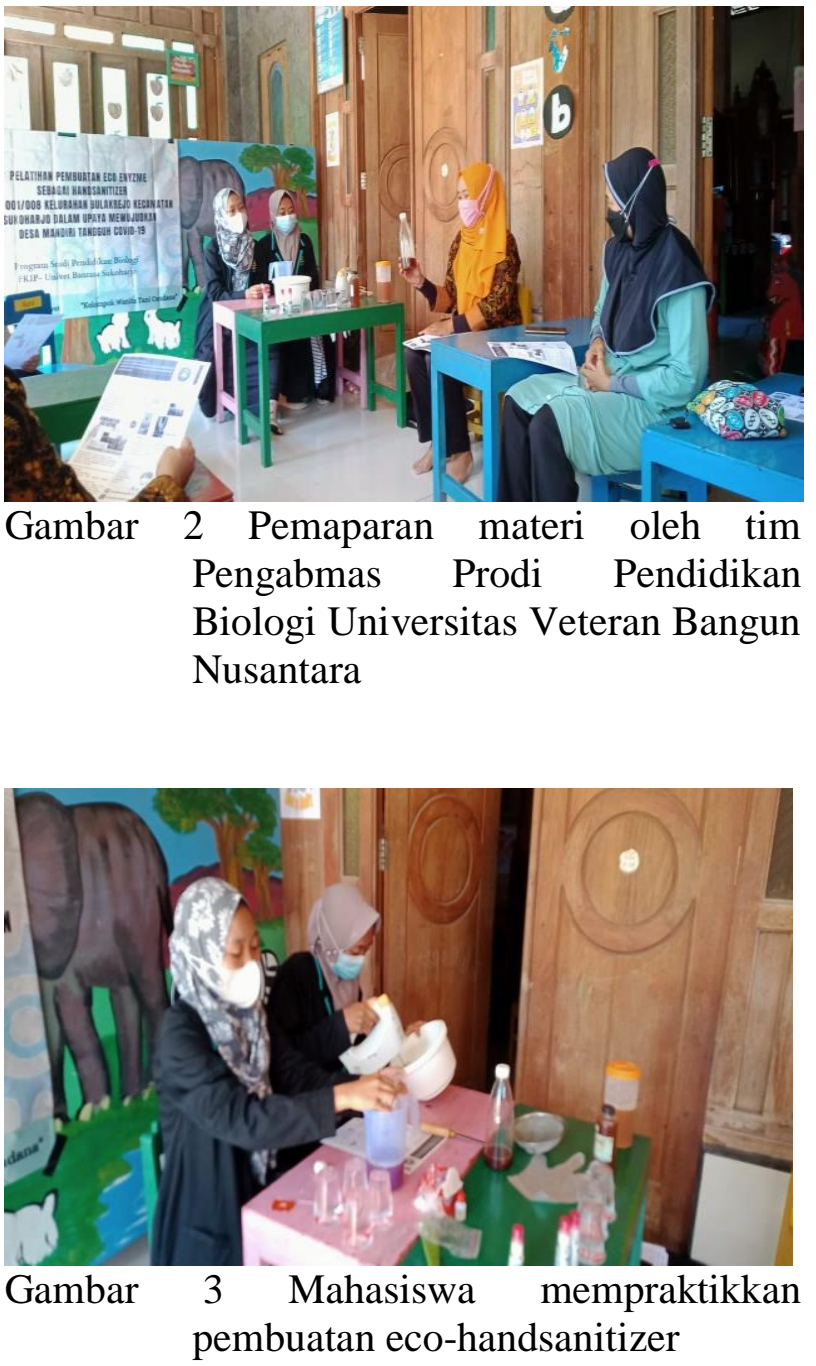

Eco-handsanitizer yang diperkenalkan oleh tim Pengabmas Prodi Pendidikan Biologi Universitas Veteran Bangun Nusantara tergolong produk baru karena ramuannya belum pernah dilaporkan sebelumnya dan sekarang dalam tahap pelaporan (Eskundari et al. (in review)). Eco-handsanitizer ini dibuat dari larutan ekoenzim dengan pengenceran sebesar $25 \%$ dan selanjutnya ditambahkan dengan gel lidah buaya serta pengawet berupa vitamin $\mathrm{E}$.

Penambahan gel lidah buaya pada ecohandsanitizer ini dimaksudkan untuk menambah manfaat dari eco-handsanitizer itu sendiri yaitu sebagai sebagai pelembut tangan sekaligus penambah daya antibakteri dari ecohandsanitizer itu sendiri. Gel lidah buaya yang ditambahkan pada produk eco-handsanitizer ini 
dibuat secara alami, yaitu dengan menghaluskan daging lidah buaya dan menyaringnya dengan saringan atau kain bersih sehingga diperoleh gel lidah buaya alami. Karena gel lidah buaya alami ini bersifat mudah rusak maka perlu penambahan vitamin E sebagai antioksidan. Terakhir, untuk menambah aroma yang meyegarkan maka ditambahkan esense teh hijau pada produk ecohandsanitizer. Dengan demikian ecohandsanitizer berhasil dibuat (Gambar 4) dan produk ini mempunyai daya hambat terhadap kuman sampai dengan 5 minggu setelah pembuatan.

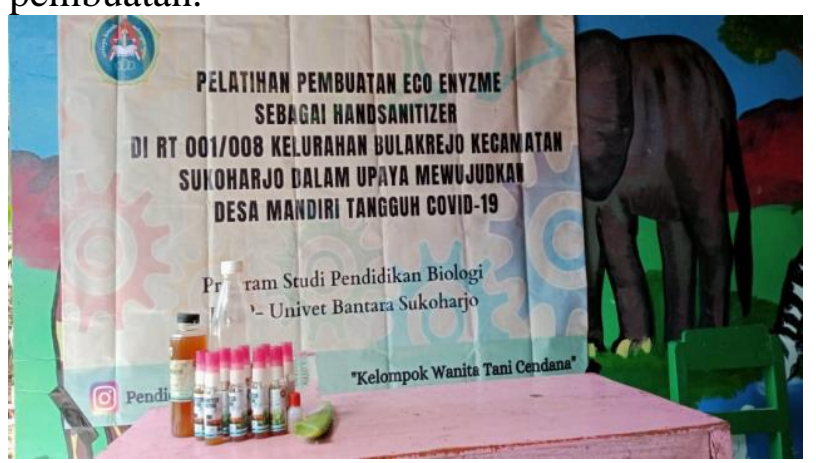

Gambar 4 Produk eco-handsanitizer yang diperkenalkan oleh Prodi Pendidikan Biologi Universitas Veteran Bangun Nusantara

Antusiasme anggota KWT dalam acara ini sangat terlihat, lebih-lebih dengan adanya pertanyaan mengenai kemampuan ecohandsanitizer dalam menghambat pertumbuhan kuman. Pertanyaan ini dapat dijawab dengan baik oleh tim Pengabmas yaitu sebelum dilakukan kegiatan Pengabmas ini, telah dilakukan uji kandungan zat aktif dalam produk eco-handsanitizer ini dan sekarang masih dalam proses pelaporan (Eskundari et al., (in review)).

Terakhir, acara ini ditutup dengan posttest terkait pembuatan eco-handsanitizer. Hasil angket menunjukkan bahwa $80 \%$ anggota KWT Cendana dapat membuat ecohandsanitizer berbahan dasar ekoenzim yang ditambahkan dengan gel lidah buaya dan vitamin E. Dengan hasil ini maka dapat dikatakan bahwa kegiatan Pengabmas ini berhasil mencapai tujuannya yaitu mengedukasi masyarakat mitra terkait diversifikasi produk ekoenzim. Terakhir, tim Pengabmas Prodi Pendidikan Biologi Universitas Veteran Bangun Nusantara berharap anggota KWT Cendana yang mengikuti pelatihan ini dapat mentransferkan ilmu ke masyarakat RT.001/008 Kelurahan Bulakrejo Kecamatan Sukoharjo Kabupaten Sukoharjo pada khususnya dan masyarakat pada umumnya.

\section{Kesimpulan}

Produk diversifikasi ekoenzim berupa handsanitizer dapat dibuat dengan mengencerkan larutan ekoenzim sebanyak 25\% serta ditambah dengan gel lidah buaya dan vitamin E. Evaluasi terhadap kegiatan Pengabmas Prodi Pendidikan Biologi Universitas Veteran Bangun Nusantara ke masyarakat mitra di RT. 001/008 Kelurahan Bulakrejo Kecamatan Sukoharjo Kabupaten Sukoharjo dapat dikatakan berhasil karena prestest menunjukkan belum ada anggota masyarakat mitra yang mengetahui tentang pembuatan eco-handsanitizer, dan setelah dilakukan penyuluhan pembuatan ecohandsanitizer ternyata sebagian besar anggota masyarakat mitra yang diwakili oleh anggota KWT Cendana telah dapat membuat ecohandsanitizer. Diharapkan informasi terkait pembuatan eco-handsanitizer dapat ditransfer ke masyarakat mitra pada khususnya sehingga dapat dijadikan salah satu upaya bertahan pada pandemi Covid-19 yang sampai saat ini belum berakhir.

\section{Saran}

Perlu dilakukan penelitian lebih lanjut dalam hal memperpanjang daya simpan ecohandsanitizer melalui penelitian lebih lanjut. 


\section{Ucapan Terima Kasih}

Penulis mengucapkan terima kasih kepada Lembaga Penelitian dan Pengabdian kepada Msyarakat (LPPM) Universitas Veteran Bangun Nusantara yang telah memberi dukungan finansial terhadap kegiatan Pengabmas ini.

\section{Daftar Pustaka}

http://lipi.go.id/siaranpress/survei-dampakpandemi-covid-19-terhadap-ekonomirumah-tangga-indonesia/22123

Lawrence, R., Tripathi, P., Jeyakumar, E. 2009. Isolation, purification, and evaluation of antibacterial agents from Aloe vera. Brazilian Journal of Microbiology, 40(4): 906-915.

Lusiana, R.A., Widodo, D.S., Suyanti, L., Gunawan, Haris, A. 2020. Edukasi pembuatan hand sanitizer berbasis lidah buaya pada masyarakat desa Harjowinangun, Grobogan. Jurnal Pengabdian Kepada Masyarakat Tabikpun, 1(1): 47-54.

Mavani, H.A.K., Tew, I.M., Wong, L. Yew, H.Z., Mahyuddin, A., Ghazali, R.A., Pow, E.H.N. 2020. Antimicrobial efficacy of fruit peels eco-enzyme against Enterococcus faecalis: An In Vitro Study. International Journal of Environment Research and Public Health, 17: 1-12. doi:10.3390/ijerph17145107.

Rahayu, M.R., Muliarta I.N., Situmeang, Y.P. 2021. Acceleration of production natural disinfectants from the combination of eco-enzyme domestic organic waste and Frangipani flower (Plumeria alba). Sustainable Environment Agricultural Science, 5(1): 15-21. 